\title{
Viabilidad de utilización de materiales de desecho procedentes de productos cerámicos en prefabricados de hormigón
}

\author{
Viability of utilization of waste materials from ceramic \\ products in precast concretes
}

\author{
M.I.SÁNCHEZ de ROJAS ",F.P.MARÍN“",M.FRÍAS',J.RIVERA* \\ (")Instituto de Ciencias de la Construcción Eduardo Torroja (CSIC)
}

(") ITECE, GrupoUralita

Fecha de recepción: 26-IX-2001

ESPAÑA

\section{RESUMEN}

Todo proceso de reciclado y revalorización de residuos implica estudios encaminados a un conocimiento profundo de los mismos, de forma que se busquen aplicaciones concretas de uso.

Los materiales de desecho procedentes de productos cerámicos pueden ser reciclados dentro del sector de la construcción, ya sea como áridos o como materiales puzolánicos.

El presente trabajo aborda la incorporación de materiales cerámicos desde estas dos vertientes, comprobando, en cada caso, el comportamiento de los morteros elaborados mediante ensayos de laboratorio. También se llevan a cabo pruebas en fábrica, siendo utilizados como componentes en prefabricados de hormigón.

\section{SUMMARY}

The recycled and re-valuation process of waste materials involves studies lead to a deep acknowledges of them, finding applications for their intended use.

The waste materials from ceramic products can be recycled into the construction sector, as arid or pozzolanic materials.

The current work deals with the incorporation of ceramic materials in these two different ways, checking the behaviour of the elaborated mortar by mean of laboratory tests. Also, tests are developed in factory, using these as components for precast concrete tiles.

\section{INTRODUCCIÓN}

A pesar de las mejoras en los procesos de fabricación, es inevitable en las industrias un rechazo de materiales considerados no aptos para su comercialización o materiales de desecho. Por otro lado, la necesidad de reparaciones y mejora de edificios es causa del aumento de los materiales de demolición, que se incrementará con la nueva Normativa del Ministerio de Fomento para la Inspección Técnica de Edificios. Estos hechos se traducen en una mayor necesidad de

\section{INTRODUCTION}

In spite of the improvements in manufacturing process, the factories produce important amounts of material considered no apt for its trading or as waste material. On the other hand, there is other production sources of waste ceramic products, as the waste coming from the repairs and improvements in the buildings, which will increase with the new "Normativa del Ministerio de Fomento para la Inspección Técnica de Edificios". 
vertederos, ya que cuando éstos no existen o no están a distancias prudenciales, pueden darse casos de vertidos incontrolados que perjudiquen el entorno ambiental.

En los últimos años, han surgido a nivel mundial iniciativas para controlar y regular la gestión de los vertidos, existiendo cada vez regulaciones más estrictas, que repercutirán económicamente a favor de opciones, poco frecuentes hoy en día, como son la minimización y reciclado.

En este sentido, recientemente ha tenido lugar la aprobación del Plan Nacional de Residuos de Construcción y Demolición (PNRCD) 2001-2006 (1). Estos residuos (RCDs) proceden en su mayor parte de derribos de edificios o de rechazos de los materiales de construcción.

En un principio, estos materiales pueden ser considerados inertes, por tener un poder de contaminación relativamente bajo. Sin embargo, su impacto visual es elevado, por el gran volumen que ocupan y por el escaso control ambiental ejercido sobre los terrenos que los contienen.

Con arreglo a la legislación española, Ley 10/1998 de Residuos, la competencia sobre su gestión corresponde a las Comunidades Autónomas, a excepción de los procedentes de obras menores domiciliarias.

Hasta la fecha se dispone de escasos datos cuantitativos sobre el volumen de RCDs generados en España, y los que existen se suelen referir a la primera mitad de la década de los noventa, donde la situación de crecimiento de la economía y, más en concreto, en el sector inmobiliario era muy distinta a la actual.

Bajo la denominación de residuos de construcción y demolición se incluye una diversidad de materiales. Según un estudio llevado a cabo por la Comunidad de Madrid y recogido en el Plan Nacional de Residuos de la Construcción y Demolición (1), los materiales que van a vertedero contienen:

- Escombros: $75 \%$

Ladrillos, azulejos y otros cerámicos: $54 \%$

Hormigón: $12 \%$,

Piedra: $5 \%$

Arena, grava y otros áridos: $4 \%$

- Madera: 4\%, Vidrio:0,5\%, Plástico: 1,5\%, Metales: 2,5\%, Asfalto: 5\%, Yeso: 0,2\%, Papel: 0,3\%, Basura: 7\% y Otros: $4 \%$.

En el seno de la Unión Europea, las estimaciones de generación de RCDs varían desde los 720 kilogramos/ habitante/año en Alemania y Holanda a los 170 de Irlanda y Grecia, estando la media de la UE en los 480 kilogramo/habitante/año. Actualmente, la media
All these facts produce the need of a larger number of $d$ Since when they doesn't exit or they are very far away c make no control wastes, which can damage the environı

In the later years, it has arisen worldwide initiatives to control and regulate the residue management, having each time regulations more strict which will influent on the creation of new solutions as the reduction and recycled of residues.

So, in the sense the National plan of construction and demolition residues (PNRCD) 2001-2006 has been recently approved. The most of these residues ( $R C D s)$ come from the building demolition or on the rebound of the construction materials.

At first, these residues can be considered as inert materials, since their contamination powder is very low. However, its visual impact is very high since they occupy a large volume and the environmental control of this land is very low.

According to the spanish legislation, 10/1998 residues law, the autonomous Communities must control all these residues, except those come from a little houses reparations.

However, nowadays there are a few quantitative data's about the RCDs volume produce in Spain, and the scanty information recorded is of the earlier 90s where the economical and construction sectors were very different to these actually exist.

The construction residues and demolition denomination involves a great range of different materials. In according with the studied carried on by Madrid Community and recorded into Demolition and Construction residues of the National Plan (1), the most common material present in the dump are:

\author{
- Debris: $75 \%$ \\ Bricks, tiles and other ceramic material: $54 \%$ \\ Concrete: $12 \%$ \\ Stone :5\% \\ Sand, grave and other arids: $4 \%$ \\ - Wood: 4\%, Glass: 0.5\%, plastic: 1.5\%, Metals: \\ 2.5\%, Asphalt: 5\%, Gypsum: 0.2\%, Paper: 0.3\%, \\ Rubbish: $7 \%$ and Other: $4 \%$.
}

In the European Union, the amount of RCDs varies from the $720 \mathrm{~kg} / \mathrm{hab} /$ year in Germany and Holland to the $17 \mathrm{~kg} / \mathrm{hab} / \mathrm{year}$ in Ireland and Greece, being the EU average of $480 \mathrm{~kg} / \mathrm{hab} /$ year. Nowadays, the recycled 
comunitaria sitúa el reciclaje de RDCs entre 25-30 \% de la producción, terminando el resto en vertedero (1). Holanda, Bélgica y Dinamarca, con el 90,87 y $81 \%$ respectivamente, son los países con mayores porcentajes de productos reutilizados o reciclados, mientras que España con menos del $5 \%$ es de los que menos recicla. Sin embargo, el actual Plan Nacional de Residuos recoge, entre sus objetivos ecológicos, que se recicle o reutilice, al menos, el $40 \%$ de RCDs en el año 2005 y el $60 \%$ en el 2006.

En España se fabrican más de 21 millones de toneladas/año de materiales cerámicos (ladrillos, tejas, bloques, etc.). El porcentaje de productos rechazados para la venta $y$, por tanto, de desecho, depende del tipo de instalación y requerimientos del producto.

Los productos cerámicos proceden de materiales naturales, que contienen una proporción elevada de minerales arcillosos. La activación de las arcillas se logra mediante un proceso de deshidratación, seguido de la separación de alúmina amorfa y activa. Los minerales arcillosos tipo kaolinita o montmorillonita, o una combinación de ambos, adquieren propiedades puzolánicas mediante calcinación controlada a temperaturas entre $540^{\circ}$ y $980^{\circ} \mathrm{C}$. Cuando las arcillas son de tipo illíticas, y los esquistos arcillosos contienen proporciones elevadas de vermiculita, clorita y micas se necesitan temperaturas superiores para su activación $(2$, $3,4)$.

En este trabajo, se estudian tres productos de desecho, procedentes del sector cerámico, comprobando su aplicación como áridos en morteros y como materiales puzolánicos. Estos ensayos se realizan empleando metodologías de laboratorio y, posteriormente, se llevan a cabo pruebas en la fabricación de tejas de hormigón, como experiencia piloto.

\section{ESTUDIOS EXPERIMENTALESY DISCUSIÓN DE RESULTADOS}

\subsection{Pruebas de laboratorio}

\subsubsection{Materiales}

\section{Materiales cerámicos}

Se trata de 3 productos procedentes de diferentes materiales cerámicos, calcinados a distintas temperaturas.

Producto A: material de desecho a temperatura de cocción adecuada

Producto B: material de desecho por cocción inadecuada (temperatura superior)
RDCs average in the EU is between 25 and $30 \%$ of the production and, the rest of them are deposited at dumps (1). Holland (90\%), Belgium (87\%), Denmark (81\%) are the countries which recycle more residues in Europe, whereas Spain only recycle less a 5\%. So, The Residues National Plan (1) pick between its ecological objectives the reusing of, at least, the $40 \%$ in 2005 and $a \quad 60 \%$ in 2006.

Spain produced more than 21 million tons/year of ceramic material (bricks, tiles, blocks, etc). The amount of rejected products by the factory for sales, depending on the manufacture type and product requirements.

The ceramic products come from natural materials, which contain a large percentage of clayey minerals. The activation of clay reaches by means of the deshydration process, followed by the separation of amorphous and active alumina. The clayey minerals such as Kaolinite, mormorillonite or mixtures between them become pozzolanic materials by mean of a controlled calcined process $\left(540^{\circ}-980^{\circ} \mathrm{C}\right)$. As the clays are illites or contain large amount of vermiculite, chlorite and micas will be necessary to use higher temperatures for its activation $(2,3,4)$.

This paper studies three waste materials coming from ceramic sector, researching their applications as arid in mortar and as pozzolanic materials in cement paste. These tests are developed using laboratory methods in order to check their characteristics and then these materials will test in the concrete tile production as a pilot experience.

\section{EXPERIMENTAL STUDIES AND RESULT DISCUSSION}

\subsection{Laboratory tests}

\subsubsection{Materials}

\section{Ceramic materials}

There are three waste materials from ceramic materials calcined at different temperatures:

\section{A: adequate firing temperature}

$B$ : inadequate firing temperature (higher temperature) 
Producto C: material de desecho por cocción inadecuada (temperatura inferior)

Los materiales de arcilla cocida posen una composición química semejante a otros materiales puzolánicos. Presentan un fuerte carácter ácido, con predominio de sílice, alúmina y óxido de hierro (alrededor 94\%) (5).

Su composición mineralógica se estudia mediante Difracción de Rayos X. El producto A está formado por cuarzo, moscovita, augita y montmorollonita, como compuestos cristalinos principales. El difractograma del producto $B$ pone de relieve la presencia de anortita y cuarzo, mientras que el producto $\mathrm{C}$ tiene como compuestos cristalinos mayoritarios un silicoaluminato cálcico magnésico y cuarzo.

Estos materiales se someten en el laboratorio a un proceso de trituración para su utilización como áridos (tamaños de partículas $<5 \mathrm{~mm}$ ) y de molienda para su uso como materiales puzolánicos (tamaños de partícula $<45$ micras).

\section{Caracterización de materiales para su utilización como áridos}

Como áridos se emplean los productos A y B, cuyas curvas granulométricas se recogen en las Figura 1.

Como puede observarse, ambos materiales presentan distribuciones granulométricas semejantes, aunque el producto $\mathrm{B}$ es ligeramente más fino que el producto $\mathrm{A}$.

\section{Caracterización de los materiales como puzolanas}

Como puzolanas se utilizan los productos de desecho $\mathrm{A}, \mathrm{B}$ y C molidos, que presentan las siguientes superficies específicas Blaine:

Producto A: $6,000 \mathrm{~cm}^{2} / \mathrm{g}$

Producto B: $5,700 \mathrm{~cm}^{2} / \mathrm{g}$

Producto C: $5,000 \mathrm{~cm}^{2} / \mathrm{g}$

La evaluación de la actividad puzolánica de los materiales se realiza mediante un método acelerado, en el que se estudia la reacción del material con una solución saturada de cal en el tiempo. La cal fijada por la muestra (\%) se obtiene por diferencia de la concentración de la solución saturada de cal inicial y el $\mathrm{CaO}$ presente en la solución en contacto con la muestra, al final de cada período prefijado (5).

Estos ensayos ponen de relieve que se tratan de productos con actividad puzolánica aceptable, ya que el porcentaje de cal fijada, a la edad de 1 día, en la muestra A es del 46\%, 26\% para la muestra B y del

\section{C: inadequate firing temperature (lower temperature)}

The chemical composition of the calcined clay is similar to other pozzolanic materials. These have a strong acid character due to the high contents of silice, alumine and iron oxide (about 94\%) (5).

Its mineralogical composition is studied by mean of $X$ Ray Diffraction. Quartz, augite and montmorillonite as main crystalline compounds form the product $A$. The $x$-ray patterns for the product $B$ shows the presence of anorthite and quartz and, for the product $\mathrm{C}, \mathrm{Mg}-\mathrm{Ca}$ silico-aluminate and quartz as predominant compounds.

These materials are crushed as arid $(<5 \mathrm{~mm})$ and then ground as pozzolanic materials $(<45 \mu \mathrm{m}$ calcined clay)in laboratory.

\section{Materials characterisation used as aggregates}

The products $A$ and $B$ are used as aggregates, and their granulometric curves are shown in the Figure 1.

It can be observed that both have granulometric distributions very similar, although the $B$ product is slightly finer than the product $A$.

\section{Materials characterisation used as pozzolans}

Waste materials $A, B$ y $C$ are used as pozzolanic materials. The followings Blaine specific surface area show below:

\section{Product A: $6,000 \mathrm{~cm}^{2} / \mathrm{g}$ \\ Product B: $5,700 \mathrm{~cm}^{2} / \mathrm{g}$ \\ Product $C: 5,000 \mathrm{~cm}^{2} / \mathrm{g}$}

The evaluation of the pozzolanic materials activity is determined by means of an accelerated method that studies the reaction of the material the fixed lime with a saturated lime solution. Lime fixed by the sample (\%) is obtained by difference between the initial concentration of saturated lime solution and the $\mathrm{CaO}$ present in the solution in contact with the sample, at the different fixed times (5).

These tests show that the raw materials studied have a acceptable pozzolanic activity, since the fixed lime at 1 day is of $46 \%, 26 \%$, and $11 \%$ for $A, B$ and $C$ 
$11 \%$ para la muestra $\mathrm{C}$, que es más lenta en mostrar su actividad, debido, posiblemente, a su menor finura. A los 3 días las muestras se igualan, fijando aproximadamente un $50 \%$ de cal, evolución que se mantiene hasta la edad de 28 días, en la cual se da por finalizado el ensayo (Figura 2). Estos resultados indican que la temperatura de cocción de estos materiales cerámicos (alrededor de $900^{\circ} \mathrm{C}$ ) es suficiente para que tenga lugar la activación de las arcillas y que adquieran propiedades puzolánicas.

\section{- Cemento}

El cemento utilizado, es un CEM II/A-V 42,5 R, según la norma UNE 80 301: 1996 (6). La elección de este cemento se debe a que éste es el más frecuente en las fábricas, en las que se llevan a cabo las pruebas con los materiales de desecho mencionados.

\section{- Arena}

La arena empleada es una arena normalizada, según la norma UNE EN 196-1:1994 (7), con un contenido de sílice superior al $98 \%$ y un tamaño de partícula menor a $2 \mathrm{~mm}$.

\subsubsection{Dosificaciones}

La elaboración y dosificación de los morteros se realiza según la norma UNE EN196-1:1994 (7). La composición, en masa, de los morteros está formada por 1 parte de cemento y 3 de arena, con una relación agua/cemento de 0,5 .

Los materiales de desecho cerámicos se utilizan:

\section{- Como áridos, sustituyendo un $20 \%$ de la arena}

- Árido: $80 \%$ arena normalizada $+20 \%$ material cerámico $(<5 \mathrm{~mm})$

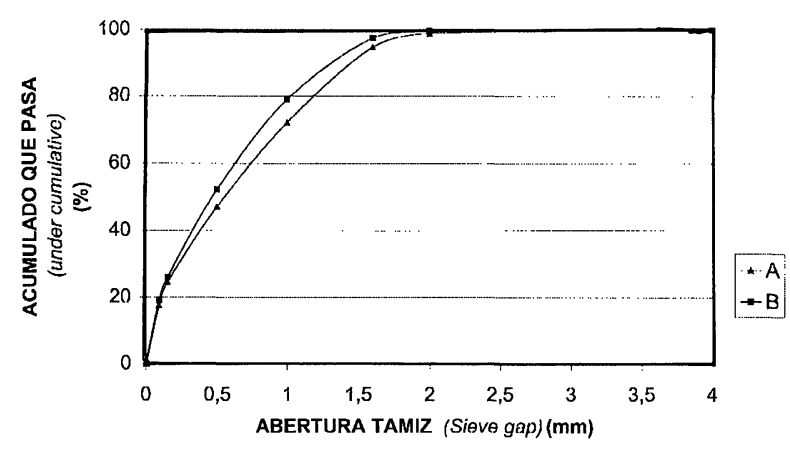

Figura 1.- Curvas granulométricas.

Figure 1.- Granulometric curves. the same activity, being the fixed lime around the $50 \%$, this evolution follows up to 28 days when the test finish (Figure 2). These results indicate that the firing temperature of these materials (around $900^{\circ} \mathrm{C}$ ) is enough to activate the clays, giving them pozzolanic properties.

\section{- Cement}

The cement is a CEM II/A-V 42,5 R, according to UNE 80301: 1996 Standard (6). This cement was chosen, because it is usually used in the concrete tiles factory, where these waste material will be tested.

\section{- Sand}

Standard sand according to UNE EN 196-1: 1994 standard (7), with a silice content upper to $98 \%$ and with a size particle less than $2 \mathrm{~mm}$.

\subsubsection{Dosage}

The mortar elaboration and dosage is done according to UNE EN 196-1:1994 (7) Standard (7). The mortar composition is 1/3 by mass (cement/sand) and the water/cement ratio is 0.5 .

The ceramic waste materials used:

- As arid, replacing a $20 \%$ of sand

- Arid: $80 \%$ Standard Sand $+20 \%$ ceramic material $(<5 \mathrm{~mm})$

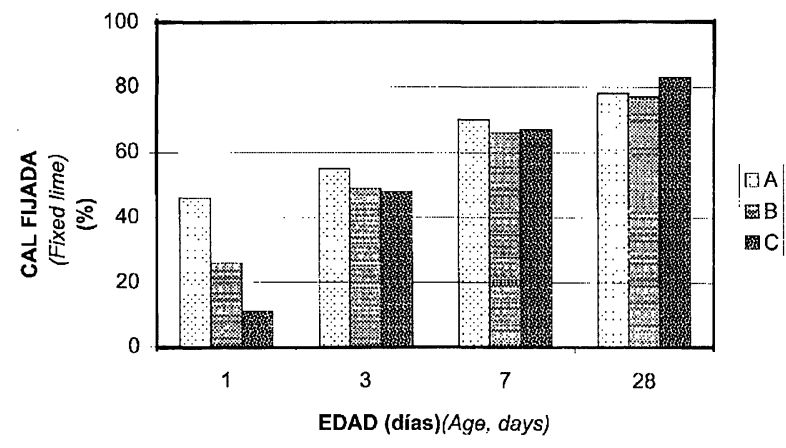

Figura 2.- Actividad puzolánica.

Figure 2.- Pozzolanic activity. 
- Cemento: $100 \%$ cemento

- Relación agua/cemento: 0,5

- Como puzolanas, incorporados en $15 \%$ en sustitución de cemento

- Arido: $100 \%$ arena normalizada

- Cemento: $85 \%$ cemento +' $15 \%$ material cerámico (<45 micras).

- Relación agua/cemento: 0,5

A los morteros fabricados se les asigna las siguientes referencias:

N.1: Mortero patrón ( $100 \%$ de cemento/ $100 \%$ arena) N.2: Mortero con producto A sustituyendo el $20 \%$ de arena

N.3: Mortero con producto B sustituyendo el $20 \%$ de arena

N.4: Mortero con producto A sustituyendo el $15 \%$ de cemento

N.5: Mortero con producto B sustituyendo el $15 \%$ de cemento

N.6: Mortero con producto C sustituyendo el $15 \%$ de cemento

\subsubsection{Resistencia mecánica de los morteros}

Los resultados de las resistencias a flexión y a compresión de las probetas de $4 \times 4 \times 16 \mathrm{~cm}$ realizadas a las edades de 24 horas y 28 días, se recogen en las Figuras 3 y 4 .

Como puede observarse las resistencias a flexión, obtenidas a 24 horas, no varían significativamente. Sin embargo, a 28 días, en todos los casos se obtienen valores ligeramente inferiores al mortero N.1 de referencia.

En las resistencias a compresión tampoco se observan variaciones importantes. Así, a 28 días experimenta un

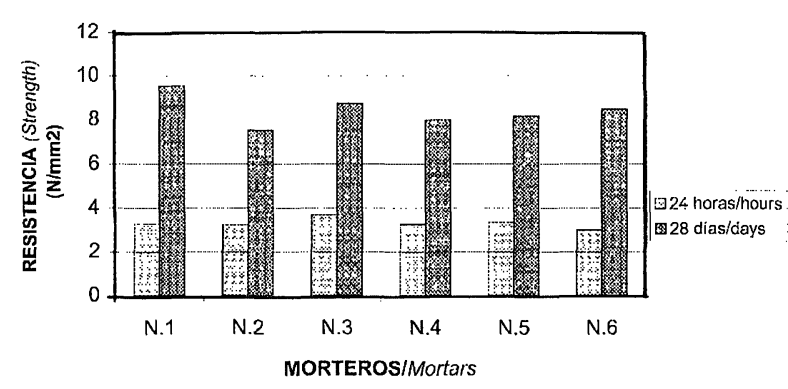

Figura 3.- Resistencia a flexión.

Figure 3.- Flexion strength resistance.
- Cement: $100 \%$ cement

- Water/cement: 0.5

- As pozzolans, replacing a $15 \%$ of cement

- Arid: $100 \%$ standard sand

- Cement: $85 \%$ cement $+15 \%$ ceramic material $(<\mu 45)$

- Water/cement: 0.5

The mortar produced are:

N.1: Reference mortar (100\% cement $1100 \%$ sand)

N.2: Mortar with product $A$, replacing a $20 \%$

of sand.

N.3: Mortar with product B, replacing a $20 \%$

of sand

N.4: Mortar with product $A$, replacing a $15 \%$ of cement

N.5: Mortar with product $B$, replacing a $15 \%$ of cement

N.6: Mortar with product $C$, replacing a $15 \%$ of cement

\subsubsection{Mortar mechanic strengths}

The results of the flexion and compression strength of the $4 \times 4 \times 16$ specimens at 24 hours and 28 days are shown in the Figures 3 and 4.

The flexion strengths at 24 hours do not vary significantly. At 28 days of curing, the values obtained are slightly lower than reference mortar in all cases.

The compression strength results do not show important changes. So, at 28 days, an increase of

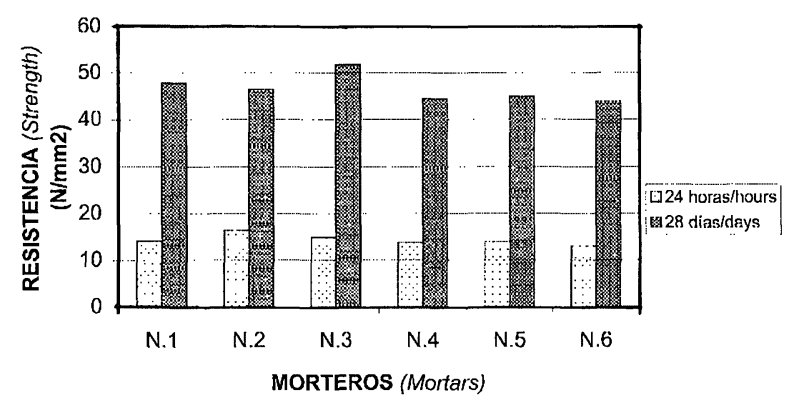

Figura 4.- Resistencia a compresión.

Figure 4.- Compression strength resistance. 
aumento de un $8,6 \%$ en el caso del producto B (N.3), y una disminución de un $2,6 \%$ con el producto A (N.2).

Para los morteros N.4, N.5 y N.6, con un $15 \%$ de sustitución de cemento, las resistencias a compresión disminuyen ligeramente, pero en todos los casos el porcentaje de disminución (entre $6 \%$ y $8 \%$ ) es inferior al grado de sustitución de cemento, lo que indica que los materiales de desecho actúan como puzolanas, aportando resistencia.

\subsubsection{Estudio de la porosidad}

La porosidad está estrechamente ligada al comportamiento permeable de los materiales. Existen estudios que ponen de relieve la relación existente entre la distribución de tamaños de poros y la permeabilidad al agua $(8,9)$, estableciendo que los poros superiores a $1.000 \AA(0,1$ micra $)$ son los que afectan en mayor medida.

Los resultados obtenidos (Tabla I) indican que los materiales de desecho utilizados no provocan, en general, un aumento significativo de la porosidad total. El caso más desfavorable tiene lugar con la incorporación del producto $\mathrm{B}$, ya que la porosidad del mortero aumenta un $6 \%$ cuando el producto se utiliza como árido (N.3) y un 7\% cuando se incorpora como material puzolánico (N.5). Sin embargo, estos ligeros aumentos en la porosidad total, no afectan a la densidad aparente, ni al diámetro medio de poro. El mortero N.5 es el que presenta un mayor diámetro medio de poro ( $1,6 \%$ superior que en el mortero de referencia). compressive strength of $8.6 \%$ for $N .3$ and a decrease of $2.6 \%$ for $N .2$ is observed.

For the mortars N.4, N.5, and N.6 with a $15 \%$ of replacement, the compression strengths decrease slightly compare with the reference mortar, but those are less than the percentage of cement substitution, indicating that these materials act as pozzolanic material contributing to the compression strength.

\subsubsection{Porosity study}

The porosity is closely related to the permeable behaviour of materials. There are studies that show the relation between the pore size distribution and the permeability $(8,9)$, indicating that the pores bigger than $1.000 \AA(0.1 \mu \mathrm{m})$ are responsible of its permeability.

The porosity results (Table I) show that these ceramic products do not provoke, in general, a significative increase in the total porosity, being the worst of all the $B$ product. In this case, the porosity increases $a$ $6 \%$ and $7 \%$ for the samples $N .3$ and $N .5$ respectively. However, theses variations do affect neither to the apparent density nor to the mean pore diameter. This fact is clearly observed for the mortar N.5 which median pore diameter is $1.6 \%$ higher than reference mortar.

TABLA $1 /$ TABLE 1

Porosidad / Porosity

\begin{tabular}{|c|c|c|c|c|c|c|}
\hline $\begin{array}{l}\text { MORTEROS } \\
\text { (MORTARS) }\end{array}$ & N.1 & N. 2 & N.3 & N.4 & N.5 & N. 6 \\
\hline $\begin{array}{l}\text { POROSIDAD } \\
\text { TOTAL } \\
\text { TOTAL } \\
\text { POROSTTY } \\
(\%)\end{array}$ & 13,77 & 13,98 & 14,81 & 13,17 & 14,54 & 13,68 \\
\hline $\begin{array}{c}\text { DENSWDAD } \\
\text { APARENTE } \\
\text { (APPARENT } \\
\text { DENSITY) } \\
(\boldsymbol{g} / \mathrm{ml})\end{array}$ & 2,46 & 2,43 & 2,47 & 2,46 & 2,46 & 2,46 \\
\hline $\begin{array}{l}\text { DLÁMETRO } \\
\text { MEDIO DE } \\
\text { PORO } \\
\text { (MEDUN PORE } \\
\text { DUMETER) } \\
(\mu \mathrm{m})\end{array}$ & 0,0184 & 0,0134 & 0,0177 & 0,0179 & 0,0187 & 0,0185 \\
\hline
\end{tabular}


En cuanto a la distribución de los tamaños de poros (Figuras 5 y 6), todos los morteros presentan resultados semejantes, no observándose aumento en los poros de mayor diámetro (superiores a 0,1 micra), que podrían causar efectos negativos en la permeabilidad. En el caso del mortero N.2, existe una mayor discrepancia en la curva de tamaños de poros, pero las diferencias se encuentran en los poros inferiores a 0,05 micras.

\subsubsection{Estereomicroscopía}

Con la lupa se estudia la textura de los morteros, comprobando cómo en el mortero N.2, el árido cerámico A queda completamente embebido en la masa, junto con el árido natural silícico, mostrando una buena adherencia pasta-árido (Foto 1).

En el caso del mortero N.4, el material cerámico A está formando parte de la masa cementante (Foto 2), observándose una buena homogeneidad de la pasta formada.

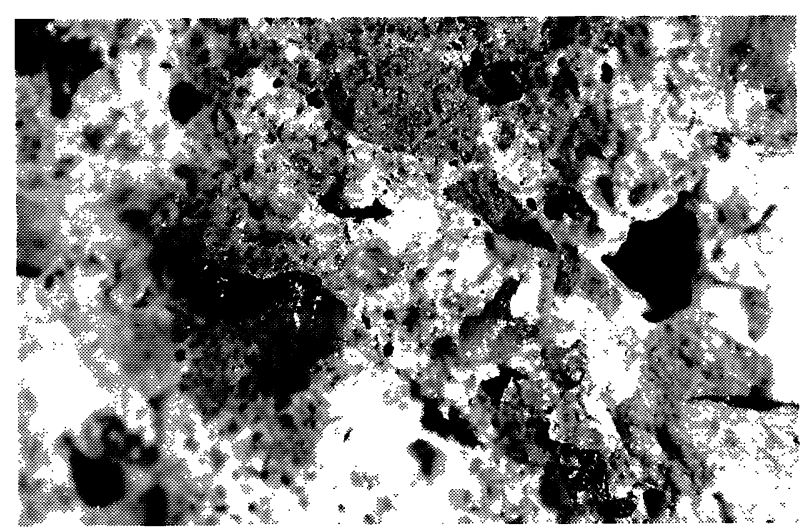

Foto 1.- Mortero N.2. observación de producto cerámico A como árido.

Photo 1.- Mortar N.2. Ceramic product A as arid.
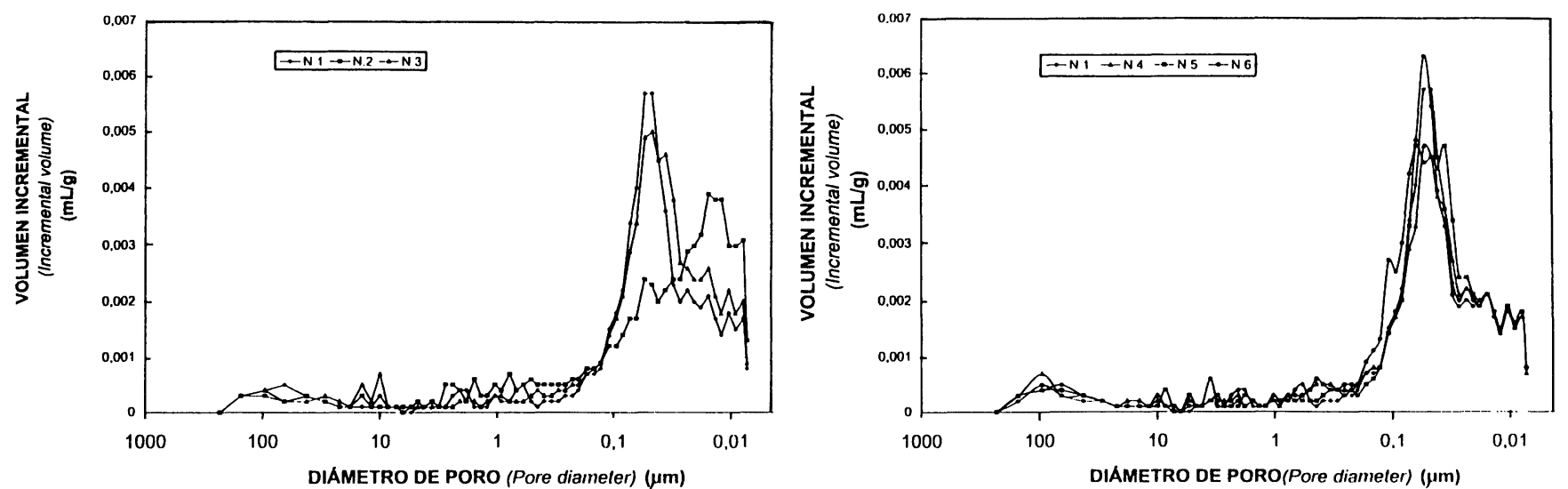

Figuras 5 y 6.- Distribución de poros

Figures 5 and 6.- Pore distribution.
Regarding to the pore size distribution (Figures 5 and 6), all mortars present similar results, observing no increase of pore sizes above $0.1 \mu \mathrm{m}$. So, these raw materials do not alter the permeability of the mortars. The sample N.2 shows some differences in the pore size curves under $0.05 \mu \mathrm{m}$.

\subsubsection{Stereomicroscopy}

The lens shows the texture of mortars. In the sample N.2 the ceramic arid $A$ is absolutely absorbed in the bulk showing a very good adherence arid-paste (Photo 1).

In the case of the sample N.4, the ceramic material A is forming part of the cementitious mass, showing a very homogenous blended paste (Photo 2).

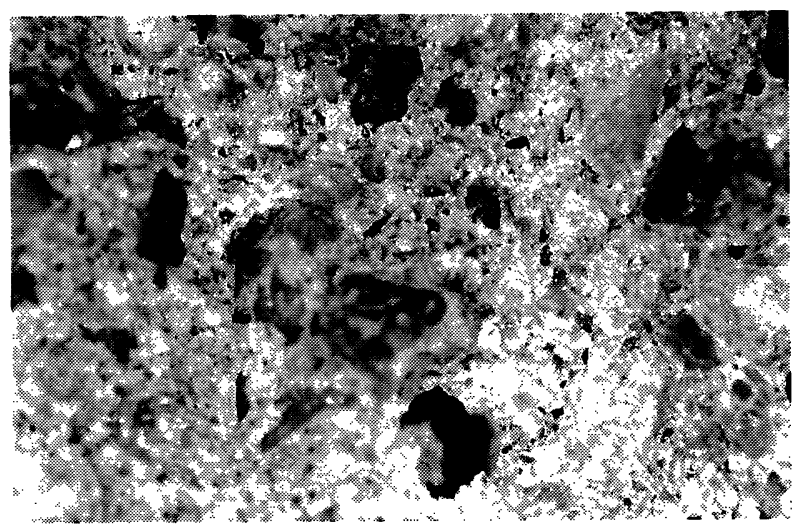

Foto 2.- Mortero N.4. Aspecto de la pasta cementante constituida por cemento/producto cerámico $\mathrm{A}$.

Photo 2.- Mortar N.4. Cementitious paste formed by cement/product A.

DIAMETRO DE PORO(Pore diameter) ( $\mu \mathrm{m})$ 


\subsection{Pruebas en fábrica}

Las pruebas realizadas en fábrica, se centran en la incorporación de los productos cerámicos de desecho como componentes en la fabricación de tejas de hormigón.

Para este fin, se cuenta con la colaboración de dos fábricas, en las que se llevan a cabo las experiencias piloto.

\subsubsection{Materiales}

\section{- Materiales cerámicos}

Para llevar a cabo este tipo de pruebas en fábrica, los materiales cerámicos, que en las pruebas de laboratorio se estudiaron por separado, se unifican en un solo producto, ya que no se observaron diferencias importantes entre ellos.

- Para su incorporación como sustituyente del árido, se realizan procesos de trituración y separaciones granulométricas, que permitan que la mezcla (árido natural + árido cerámico) se ajuste a la granulometría utilizada en la fabricación de tejas de hormigón.

- Su aplicación como materiales puzolánicos requiere de un proceso de molienda hasta conseguir la finura adecuada. En este caso, las muestras se muelen en molinos industriales a dos finuras diferentes, expresadas como superficie específica Blaine:

. Producto con finura A: $3,500 \mathrm{~cm}^{2} / \mathrm{g}$

. Producto con finura B: $3,200 \mathrm{~cm}^{2} / \mathrm{g}$

\section{- Cemento}

Cada fábrica utiliza un cemento diferente, que se detalla en cada caso.

\section{- Arena}

La arena o mezclas de arenas son naturales y de tipo silíceo. Con una curva granulométrica, que tiene que situarse dentro de un intervalo o uso definido en cada fábrica.

\subsubsection{Utilización como áridos}

Las pruebas se llevan a cabo sustituyendo $5 \%$ y $10 \%$ respectivamente, de arena natural silícea por producto cerámico. En esta fábrica se emplea un cemento CEM I 42,5 R, según la normativa vigente (6).

\subsection{Factory test}

The factory tests are focussed on the incorporation of ceramic products as component in the concrete tile production.

For this objective, two factories participate directly in order to carry out the pilot experiences.

\subsubsection{Materials}

\section{- Ceramic materials}

To carry out these tests in the factory, the ceramic material used comes from the mixture of three products studied in laboratory, since they do not show important differences.

- For the incorporation of the ceramic material as arid, it is crushed and sieved to obtain a mixture (natural arid + ceramic arid) with the same granulometric distribution that the (natural arid) normally used in the manufacture of concrete tiles, by means of industrial mill.

- For the incorporation of the ceramic material as pozzolanic materials is ground up to obtain a powder with two different Blaine specific surface areas:

. Product A: $3,500 \mathrm{~cm}^{2} / \mathrm{g}$

. Product B: $3,200 \mathrm{~cm}^{2} / \mathrm{g}$

\section{- Cement}

Each factory utilises different cement, which is specified in each case.

\section{- Sand}

The sand or sand mixtures are natural and siliceous nature, with a granulometric distribution between the ranges established in each factory.

\subsubsection{Utilization as aggregates}

The tests are developed replacing 5\% and $10 \%$ of natural sand by ceramic product. This factory uses a CEM I 42,5 $R$ cement, according to existing standard (6). 
En las tejas de hormigón fabricadas se lleva a cabo el ensayo de resistencia a flexión transversal, recogido en las especificaciones de la norma UNE EN 490 (10), según el método detallado en la norma UNE EN 491 (11). Los resultados de las resistencias medias se recogen en la Figura 7.

Las resistencias medias a flexión transversal de las tejas fabricadas con $5 \%$ de sustitución de arena por árido cerámico son muy semejantes a las correspondientes a la teja de hormigón sin material cerámico $(0 \%)$, aunque a los 28 días son ligeramente inferiores (disminución de un 3\%).

Cuando se sustituye un $10 \%$ de arena por material cerámico, se observa una bajada de la resistencia media a flexión transversal a las primeras 24 horas (disminución de un 19\%), aunque con el tiempo los resultados tienden a igualarse con los de la teja de hormigón tradicional (disminución de un $12 \%$ a 7 días y un $5 \%$ a 28 días).

Las tejas elaboradas con los productos cerámicos cumplen con el ensayo de impermeabilidad y heladicidad, contemplados en la norma UNE EN 490 (10), según la metodología de ensayo recogida en la norma UNE EN 491 (11), aunque prolongando los ciclos de heladicidad ( $>400$ ciclos) por encima del estipulado en la normativa ( 25 ciclos), se observa que la resistencia resultante es inferior a la de la teja de referencia.

\subsubsection{Utilización como materiales puzolánicos}

Como se ha mencionado anteriormente, en las pruebas en fábrica se utilizan materiales cerámicos de desecho, con dos superficies específicas Blaine distintas: A $\left(3.500 \mathrm{~cm}^{2} / \mathrm{g}\right)$ y B $\left(3.200 \mathrm{~cm}^{2} / \mathrm{g}\right)$ y tres grados de sustitución de cemento diferentes: $5 \%, 10 \%$ y $15 \%$.

El cemento utilizado en esta fábrica es un CEM II/A-V 42,5 R (6).

Las pruebas realizadas son:

Prueba 0: producción normal de tejas de hormigón Prueba 1: sustitución 5\% de cemento por material cerámico, finura A

Prueba 2: sustitución $10 \%$ de cemento por material cerámico, finura A

Prueba 3: sustitución $15 \%$ de cemento por material cerámico, finura A

Prueba 4: sustitución 5\% de cemento por material cerámico, finura B

Prueba 5: sustitución $10 \%$ de cemento por material cerámico, finura $\mathrm{B}$
In the concrete tile made with ceramic material are carried out the transversal flexion strength test, stated in the specifications of the UNE EN 490 standard (10), according to UNE EN 491 standard (11). The average strength results are showed in the Figure 7.

The average of the transversal flexion strength results of the concrete tiles made with a 5\% of replacing of sand are very similar to the reference concrete tile (0\% ceramic material), although these values decrease slightly at 28 days (3\%).

As the natural sand is replacing by $10 \%$ of ceramic material, the average transversal flexion strength decreases a 19\% at the first 24 hours, but later this results tend to be equals to the reference concrete tile $(12 \%$ at $7 d$ and $5 \%$ at 28 d).

The tiles made with the ceramic products obey the impermeability and freeze and thaw test, stated in UNE EN 490 standard (10), according to the tests of the UNE EN 491 (11) standard. Although when the ice cycles are longer (>400 cycles) than the stipulate in the Standard (25 cycles), the strength is lower than the reference concrete tile.

\subsubsection{Utilization as pozzolanic material}

As mentioned above, the experimental tests in factories use waste ceramic materials with two different Blaine specific surface areas and three different degree of cement substitution $(5,10$ and $15 \%)$.

The cement used was a CEM II/A-V $42,5 R(6)$

The tests developed in the factory were:

Test 0: normal production of concrete tiles Test 1: substitution of 5\% of cement by ceramic material, fineness $A$

Test 2: substitution of $10 \%$ of cement by ceramic material, fineness $A$

Test 3: substitution of $15 \%$ of cement by ceramic material, fineness $A$

Test 4: substitution of 5\% of cement by ceramic material, fineness $B$

Test 5: substitution of $10 \%$ of cement by ceramic material, fineness $B$ 
Prueba 6: sustitución $15 \%$ de cemento por material cerámico, finura $\mathrm{B}$

Las resistencias medias a flexión transversal de las tejas así fabricadas, en el momento del desmoldeo ( 9 horas) y a los 7 días y 28 días se presentan en la Figura 8.

Como puede observarse, las tejas con materiales cerámicos presentan, a primeras edades, unos valores de resistencia a flexión transversal semejantes a los de la teja normal (prueba 0). A los 28 días todas las tejas fabricadas con el producto cerámico experimental incrementos de resistencia respecto a la prueba patrón, comprendidos entre el $13 \%$ en la prueba 1 y $3 \%$ en la prueba 3 . Este hecho se debe a la evolución de la reacción puzolánica, cuya acción se hace patente a medio o largo plazo, dependiendo de la velocidad de reacción del material.

Estos resultados ponen de relieve que el producto cerámico utilizado actúa como puzolana y, por tanto, contribuye en el desarrollo de resistencia mecánica, de forma que se puede lograr los valores de resistencia requeridos, con un menor contenido de cemento.

Los resultados de permeabilidad en las tejas fabricadas en las distintas pruebas, son satisfactorios, cumpliendo con los requerimientos de la normativa ya mencionada $(10,11)$.

\section{CONCLUSIONES}

Los productos cerámicos procedentes de desechos industriales pueden ser utilizados en la elaboración de prefabricados de hormigón, ya sea como áridos, sustituyendo un porcentaje de árido natural, o como adiciones activas, incorporadas en sustitución de cemento.

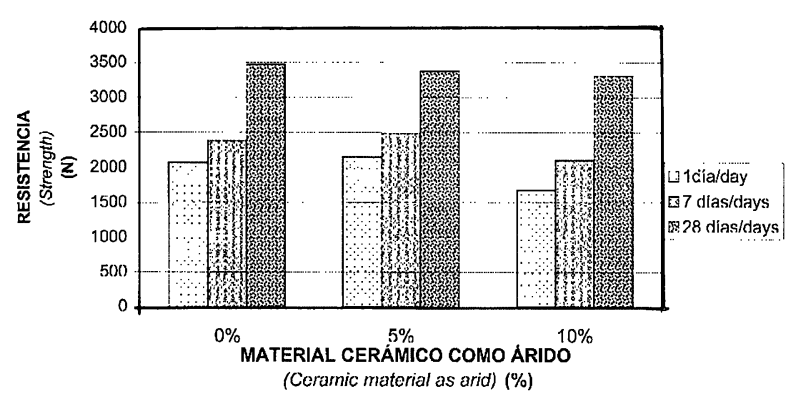

Figura 7.- Resistencia media a flexión transversal (1, 7 y 28 días).

Figure 7.- Median transversal flexion strength (1, 7 and 28 days).
Test 6: Substitution of $15 \%$ of cement by ceramic material, fineness $B$

The average flexion strengths of the tiles made in this way and, once removed from its mould $(9$ hours) and at 7 days and 28 days are in the Figure 8 .

So, at early ages the concrete tiles made with ceramic materials show a transversal flexion resistance strength data similar to the reference concrete tile (test 0), but at 28 days, this resistance increase up to $13 \%$ in the test 1 , and $3 \%$ in the test 3. This fact is due to puzzolanic reaction, which action starts a medium and long term depending on material reactivity.

All these results confirm that this waste ceramic material acts as pozzolanic material, having a positive effect on the mechanic strength. So, it possible to obtain high strength values with a lower amount of cement.

The permeability tests also show satisfactory results, obeying with the standards requirements $(10,11)$

\section{CONCLUSIONS}

The use of ceramic products from industrial waste can be used in the elaboration of precast concrete, such as arid replacing a percentage of natural arid as active addition substituting some percentage of cement.

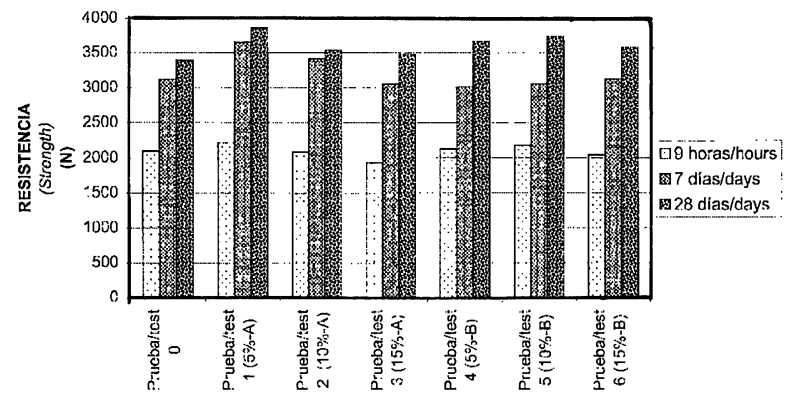

Figura 8.- Resistencia media a flexión transversal ( 9 horas y 7 y 28 días).

Figure 8.- Median transversal flexion strength $(9$ hours and 7 and 28 days). 
- Los ensayos de laboratorio muestran que los morteros con productos cerámicos, empleados como áridos, presentan resistencias mecánicas y porosidades semejantes a las del mortero de referencia. El ligero aumento de la porosidad total no incrementa el diámetro medio de poro.

En cuanto al comportamiento como materiales puzolánicos, se pone de relieve que los materiales de desecho tienden a disminuir la porosidad y aportan resistencias mecánicas gracias a la reacción puzolánica, ya que el porcentaje de disminución de resistencias es inferior al grado de sustitución de cemento.

- Los resultados obtenidos con los materiales cerámicos son satisfactorios para su uso concreto de fabricación de tejas de hormigón, tanto como sustituyentes del árido como del cemento. Esta última aplicación ofrece las mayores ventajas, ya que a los 28 días las resistencias a flexión transversal, en todas las pruebas realizadas, son siempre superiores a los de la teja de referencia, con un incremento del $13 \%$ en el caso más favorable.

La utilización de productos cerámicos en sustitución de cemento ofrece buenos resultados técnicos y también los mayores beneficios económicos. Las adiciones confieren a los cementos características positivas, particularmente desde la perspectiva de la durabilidad, ya que con la reacción puzolánica la portlandita, procedente de la hidratación del cemento, se combina con los componentes ácidos del material puzolánico, para dar lugar a productos que contribuyen al aumento de resistencia, tanto mecánica como química, a medio o largo plazo $(12,13)$.

Las ventajas económicas derivan del ahorro energético y de materias primas en el cemento. La sustitución de un material como el clínker, que requiere un elevado consumo energético, por un material con menor gasto de energía, como es un desecho industrial, aunque éste necesite de un tratamiento previo de molienda, representa un mejor aprovechamiento de los recursos, que contribuye positivamente a la conservación del medio ambiente y elimina residuos de escombreras $(13,14)$.

Por este motivo, y dados los esperanzadores resultados, actualmente se está planteando el llevar a cabo la implantación de este tipo de productos en la fabricación habitual de tejas de hormigón, por lo que se sigue avanzando en esta línea de trabajo, con la realización de nuevas pruebas, a más largo plazo, que pongan de relieve posibles variaciones de comportamiento a edades avanzadas.
- The laboratory tests show that the mortars made with ceramic products, used as arid, present mechanical strengths and porosities similar to those to the reference mortar. The slight increase on the total porosity does not increase the median pore diameter.

When the ceramic materials are used as pozzolanic materials show these reduce the porosity and provide mechanical strength due to its pozzolanic activity, since the mechanical resistance decrease less than the cement substitution degree by ceramic materials.

- The results obtained show these ceramic materials can be used satisfactorily in the manufacturing of concrete tiles, such as arids and cement as well. As pozzolanic materials, they show the best advantages. At 28 days of curing, the transversal flexion strengths are always higher that the reference concrete tiles (with an increase up to 13\%).

The utilization of ceramic materials as substitution of cement shows very good technical results and economical advantages. These ceramic materials improve the durability of the final products, since the acid components of these react with the portlandite, produced during the cement hydration, giving a new hydrated products which improve either the mechanical strengths or chemical resistance, at medium and long term $(12,13)$.

The economical advantages come from the energy saving and raw materials in cement. On one hand, the partial replacement of the clinker, which needs a very high energy consumption for its manufacture, by a waste material which need a lower energy (only a grinding process ). On the other hand, this fact represents a positive contribution to the environmental preservation and to the elimination of wastes from dumps $(13,14)$.

Based on these results, nowadays, the factory technical manager is thinking the possibility of using this kind of products in the normal production of concrete tiles. So, new researches are being carried out in order to observe possible variation at long terms 


\section{AGRADECIMIENTOS}

Estas investigaciones han tenido lugar gracias a un Proyecto de Investigación (AMB96-1095) subvencionado por la Comisión Interministerial de Ciencia y Tecnología (CICYT), así como a la colaboración de la División de Tejas Grupo Uralita.

\section{ACKNOWLEDGEMENTS}

These researches have been done under a Research Project (AMB 96-1095) supported by Technology and Science Interministerial Commission (CICYT), and the collaboration of the Tiles Division of the Uralita Group

\section{BIBLIOGRAFÍA}

(1) Plan Nacional de Residuos de la Construcción y Demolición 2001-2006. Resolución de 14 de junio de 2001, de la Secretaría General de Medio Ambiente. BOEn.166,25305-25313,12 julio(2001).

(2)J. Calleja: “Las puzolanas". Ión, Ns. 340, 341, 343 y 344, noviembre y diciembre(1969), febrero y marzo (1970), 623-638,700-713,81$90,154-160$

(3) Johansson, S; Andresen, P.J. (1990): “ Pozzolanic activity of calcined moler clay”. Cement and concrete research. V.20, 447-452.

(4) Mielenz, R.C. (1983): “Mineral admixtures- History and background". Concrete International, 34-42.

(5) Sánchez de Rojas, M.I., Frías, M. Rivera, J. Escorihuela, M.J., Marín, F.P. (2001) “Investigaciones sobre la actividad puzolánica de materiales de desecho procedentes de arcilla cocida". Materiales de Construcción, 51, N² 261,45-52.

(6) Norma UNE 80301/1996: “Cementos. Definiciones, Clasificación y Especificaciones”.

(7) Norma UNE EN 196-1/1994: "Métodos de ensayo de cementos. Parte 1: Determinación de resistencias mecánicas".

(8) Mehta, P.K; Manmohan, D. (1980): "Pore size distribution and permeability of hardened cement pastes". $7^{\text {th }}$ Inter. Congress on the Chemistry of Cement. V. III. París. VII-1-5.

(9) Nyame, B.K., Illston, J.M. (1980): "Capillary pore structure and permeability of hardened cement paste". $7^{\text {th }}$ Inter. Congress on the Chemistry of Cement. V. III. Paris. VI-181-185.

(10) Norma UNE EN 490/1995: “Tejas y accesorios de hormigón. Especificaciones de producto".

(11) Norma UNE EN 491/1995: "Tejas y accesorios de hormigón. Métodos de ensayo".

(12) Calleja, J. (1983): “Adiciones y Cementos con adiciones”. Materiales de Construcción, No 190-191, 25-52.

(13) Soria, F. (1983): "Las puzolanas y el ahorro energético en los materiales de construcción". Materiales de Construcción, N 190-191, 69-84.

(14) Calleja, J. (1992): “Los nuevos cementos europeos para hormigones”. Cemento y Hormigón, № 709, 1157-1 182. 